\title{
Keunggulan, Tantangan, dan Rekomendasi Kebijakan akan Pengembangan Energi Panas Bumi di Indonesia
}

\author{
Salma Zafirah Wisriansyah ${ }^{1,2}$, Dorman Purba ${ }^{1,3}$, Arnaldo Napitu ${ }^{1,4}$
}

\begin{abstract}
ABSTRAK
Sebagai negara yang duduk di wilayah Cincin Api Pasifik, Indonesia merupakan negara kedua terbesar yang memiliki potensi energi panas bumi di dunia. Energi panas bumi merupakan salah satu jenis energi terbarukan yang bersih sehingga tidak hanya dapat menurunkan emisi Gas Rumah Kaca (GRK) nasional namunjuga menjaga suplai energi listrik di masa mendatang. Melalui Rencana Umum Energi Nasional (RUEN), pemerintah Indonesia menargetkan pembangunan kapasitas Pembangkit Listrik Panas Bumi (PLTP) sebesar 7200 MW pada tahun 2025. Namun, per tahun 2020, Indonesia baru mampu membangun kapasitas PLTP dengan total nilai sekitar 2100 MW. Studi ini bertujuan untuk menyoroti beberapa keunggulan yang dimiliki energi panas bumi dibandingkan jenis energi terbarukan lainnya, yaitu karakteristik alaminya yang ramah lingkungan, tidakbersifatintermittent, dapat dijadikan sebagai baseload, dan tidakmembutuhkan luas area yang besar. Selain itu, studi ini juga membahas mengenai kendala terbesar yang menyebabkan lambannya pertumbuhan kapasitas PLTP dan memberikan rekomendasi strategis yang dapat diambil oleh pemerintah dalam menghadapi kendala terbesar tersebut. Hasil studi ini memperlihatkan bahwa kendala terbesar dalam pengembangan PLTP terdapat pada tahap awal eksplorasi. Beberapa upaya telah dilakukan pemerintah Indonesia dalam mendukung kegiatan eksplorasi panas bumi. Namun studi ini berargumen bahwa masih terdapat beberapa langkah yang dapat diambil pemerintah untuk lebih mendukung kegiatan eksplorasi panas bumi di Indonesia seperti pendirian badan eksplorasi panas bumi serta pembiayaan kegiatan eksplorasi. Rekomendasi kebijakan ini diharapkan dapat menjadi terobosan langkah pemerintah Indonesia dalam pencapaian target PLTP 7200 MW pada tahun 2025.
\end{abstract}

Kata kunci: panas bumi, transisi energi, energi terbarukan, kebijakan, Indonesia

\section{ABSTRACT}

As a country that sits on the Pacific Ring of Fire, Indonesia is a country that has the second largest geothermal potential in the world. Geothermal energy is a clean-renewable energy that can help the country in reducing greenhouse gas emissions and secure its electricity supply in the future. Through Rencana Umum Energi Nasional (RUEN), government of Indonesia has set the target of building geothermal power plant with the capacity of $7200 \mathrm{MW}$ by 2025. However, per 2020, Indonesia has only built roughly about 2100 MW geothermal power plant capacity. This study aims to highlight geothermal's advantages, compared to other renewable energies, such as environmentally friendly, not intermittent, capable to be the base load, and does not

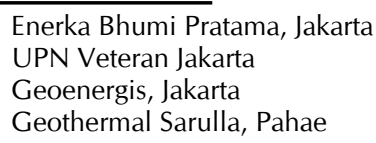


need a large area. Besides that, this study discusses the biggest obstacle causing the sluggish development of geothermal power plant and is also expected to give strategic recommendations to the government to solve this biggest obstacle. The result of this study shows that the biggest obstacle in developing geothermal power plant lies the exploration phase. Some actions had been taken by the government of Indonesia to support the exploration phase but this study believes there are still some solutions that the government needs to take in order to be more supportive of the geothermal exploration in Indonesia such as establishing geothermal-exploration entity and funding the exploration phase. These recommendations are expected to be useful in helping the government achieving 7200 MW by 2025.

Keywords: geothermal, energy transition, renewable energy, policy, Indonesia

\section{PENDAHULUAN}

Bahaya terhadap lingkungan dan keselamatan jutaan umat manusia akan krisis iklim telah memicu negara-negara di dunia untuk mulai lebih serius dalam mentrasisikan jenis energi yang digunakan menuju energi bersih terbarukan. Pemakaian energi berbasis fosil seperti batu bara dan minyak bumi telah dianggap sebagai kontributor utama penyebab krisis iklim dimana 72\% emisi Gas Rumah Kaca (GRK) di dunia berasal dari $\mathrm{CO}_{2}$ hasil pembakaran bahan bakar fosil (Olivier and Peters, 2020).

Pada tahun 2016, pemerintah Indonesia telah menyerahkan Nationally Determined Contribution (NDC) ke sekretariat PBB dalam komite United Nations Framework Conventions on Climate Change (UNFCCC). Dalam NDC tersebut, pemerintah Indonesia berkomitmen untuk menurunkan emisi GRK nasional dengan menargetkan jumlah energi terbarukan pada bauran energi nasional menjadi $23 \%$ pada tahun 2025 dan 31\% pada tahun 2050.

Selain kekhawatiran akan bahaya krisis iklim, besarnya ketergantungan Indonesia terhadap bahan bakar fosil yang semakin menipis juga menjadi salah satu motivasi utama pemerintah Indonesia dalam menyusun pathway transisi energi nasional menuju energi bersih terbarukan demi menjaga pasokan energi yang akan terus meningkat di masa mendatang.

Salah satu tantangan terbesar dalam pemanfaatan beberapa sumber energi terbarukan ialah adanya fluktuasi suplai energi yang diakibatkan karakter alami dari berbagai sumber energi seperti solar photovoltaic dan wind power. Karena energi listrik yang dihasilkan pada solar photovoltaic dan wind power sangat bergantung pada besarnya intensitas cahaya matahari dan kecepatan angin, maka kedua teknologi ini menghasilkan energi listrik yang bersifat intermittent sehingga sulit untuk dijadikan sebagai base load dalam pasokan energi listrik nasional. Jenis energi terbarukan lainnya seperti hydropower juga akan mengalami kesulitan karena musim kering yang diprediksi akan semakin tidak terprediksi akibat krisis iklim di dunia (Li et al., 2009)drought severity, production (yield.

Pada skala pembangkit listrik yang besar, belum adanya teknologi penyimpanan energi (storage) untuk menyimpan energi listrik dalam jumlah besar secara ekonomis juga menjadi salah satu kendala utama dalam pemanfaatan teknologi energi terbarukan. Selain teknologi baterai, dikenal adanya metode penyimpanan energi lain yang dinamakan pumped-storage hydropower. Namun seperti yang telah dijelaskan sebelumnya, karena musim kering yang semakin tidak terprediksi, jenis teknologi penyimpanan ini akan mengalami kesulitan dalam mendapatkan sumber energi air. Kebutuhan pumped-storage hydropower akan dam juga akan menimbulkan masalah lingkungan karena dam merupakan salah satu sumber penghasil GRK (Yang et al., 2014). 
Masalah lain yang timbul dari pemanfaatan energi terbarukan ialah kebutuhan terhadap lahan yang cukup luas. McDonald et al. (2009) memberikan perhitungan land use intensities yang akan terjadi pada tahun 2030 dalam satuan $\mathrm{km}^{2} / \mathrm{TWh} / \mathrm{yr}$ dimana solar photovoltaic memiliki nilai median land use intensities sebesar $36.9 \mathrm{~km}^{2} / \mathrm{TWh} / \mathrm{yr}$, windpower sebesar $72.1 \mathrm{~km}^{2} / \mathrm{TWh} / \mathrm{yr}$, dan hydropower sebesar $54 \mathrm{~km}^{2} / \mathrm{TWh} / \mathrm{yr}$ (McDonald et al., 2009).

Tidak hanya itu, kebutuhan akan rare earth materials seperti neodymium pada wind turbines, lithium dan cobalt pada baterai, dan silicon pada solar photovoltaic membuat pengembangan energi terbarukan menjadi lebih membutuhkan banyak pertimbangan. Kegiatan penambangan rare earth material dan mineral processing ini akan membutuhkan banyak air, bahan-bahan kimia, dan juga energi. Kegiatan ini juga akan menghasilkan waste yang harus diolah dengan baik (Judge, Xiao and Kipouros, 2017) ${ }^{1}$

Berbagai kendala inilah yang menyebabkan lambannya peningkatan pemanfaatan energi terbarukan di Indonesia. Dibutuhkan pertimbangan yang matang dan tepat sasaran sebelum pemerintah Indonesia mengambil kebijakan terkait penentuan peranan energi terbarukan dalam bauran energi nasional.

Energi panas bumi merupakan salah satu jenis energi terbarukan yang dimiliki oleh Indonesia dalam jumlah potensi yang sangat besar. Sebagai salah satu negara yang duduk pada wilayah Cincin Api Pasifik (Ring of Fire), Indonesia dianggap sebagai negara kedua terkaya akan potensi energi panas bumi di dunia dengan perkiraan sebesar 28.579 MW (Dirjen EBTKE, 2017). Namun demikian, hingga tahun 2020, Indonesia baru berhasil mem-

1 Limitation of production methods and environmental consequences: "Minerals, Metals and Materials Series" on paper-conference "Application of rare earths for higher efficiencies in energy conversion". http://www.mendeley.com/documents/?uuid = b6549b66-fc3a-4dd7-a9a72dd20b6c29e0". Judge, Xiao and Kipouros, 2017. bangun kapasitas Pembangkit Listrik Tenaga Panas Bumi (PLTP) sebesar 2100 MW atau setara dengan $7 \%$ dari total potensinya.

Studi ini akan mendiskusikan karakteristik alami energi panas bumi yang dianggap memiliki beberapa keunggulan dibandingkan jenis energi terbarukan lainnya dalam menyokong base load pasokan listrik nasional. Saat ini Indonesia masih bergantung banyak kepada batu bara dalam menjaga pasokan listrik level base load dimana penggunaan batu bara harusnya sudah mulai dibatasi karena berdampak buruk terhadap lingkungan. Studi ini juga bertujuan untuk menyoroti kendala terbesar yang menghambat pertumbuhan kapasitas PLTP di Indonesia dimana saat ini penulis berargumen kendala terbesar terletak pada lambatnya pelaksanaan tahap eksplorasi di berbagai lapangan panas bumi di Indonesia.

Studi ini juga diharapkan mampu memberikan rekomendasi langkah strategis yang dapat diambil oleh pemerintah Indonesia sebagai solusi atas kegiatan eksplorasi energi panas bumi, berdasarkan upaya-upaya yang telah dilakukan sebelumnya oleh pemerintah.

\section{TINJAUAN PUSTAKA}

Energi panas bumi merupakan energi yang berasal dari panas yang dihasilkan pada inti bumi. Berasal dari pengertian ini dapat dipahami bahwa sebenarnya semua tempat di seluruh dunia memang memiliki energi panas bumi. Namun sayangnya, dibutuhkan pengeboran beribu-ribu kilometer ke dalam bumi untuk mendapatkan energi panas tersebut. Sementara itu, energi panas bumi yang feasible hanya ada pada wilayah-wilayah tertentu saja yang mana kedalaman pengeborannya jarang melebihi $3 \mathrm{~km}$ (Fridleifsson, Bertani and Huenges, 2008).

Indonesia cukup beruntung karena posisinya 
yang duduk pada wilayah Cincin Api Pasifik. Wilayah Cincin Api Pasifik merupakan wilayah dimana terdapat tiga lempeng tektonik yang saling bertemu yaitu lempeng Pasifik, Eurasia, dan Indo-Australia. Ketiga lempeng ini bergerak secara konvergen (saling mendekati) dan biasanya menyebabkan kerak lem- peng samudera menjorok masuk ke dalam salah satu lempeng benua dikarenakan nilai densitasnya yang lebih besar. Pencampuran kedua lempeng ini akan masuk ke dalam daerah subduction zone (Masum and Ali Akbar, 2019).

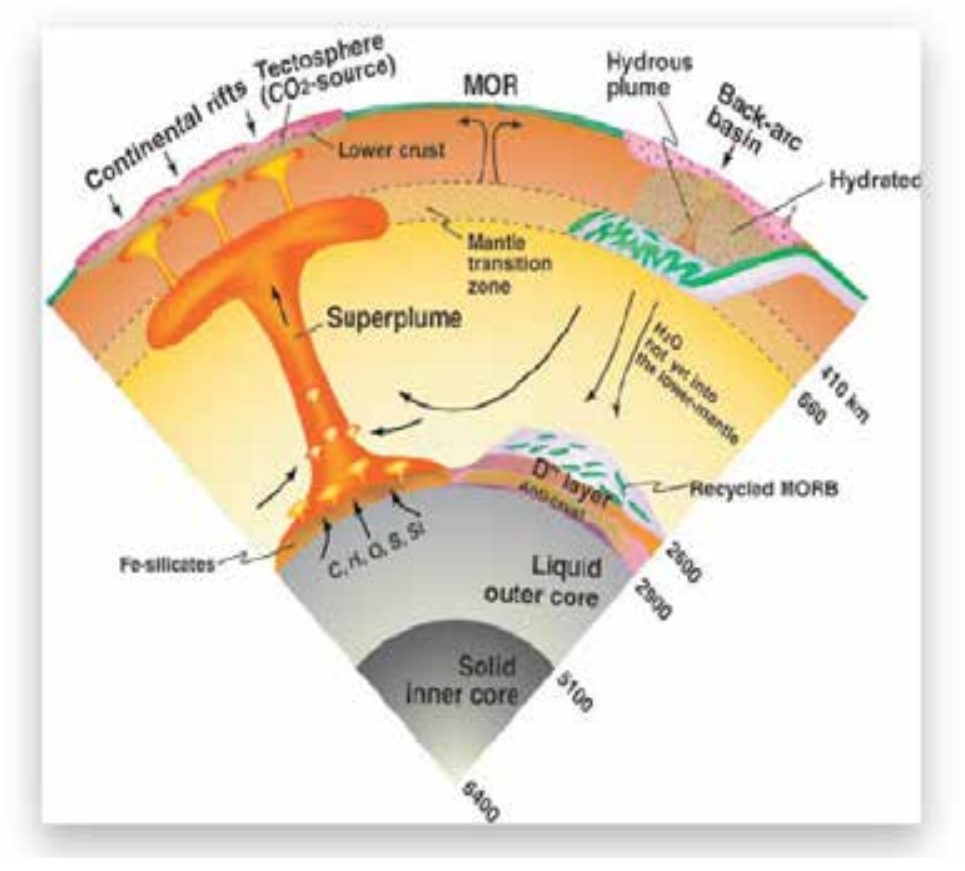

Gambar 1. Skenario Panas Bumi yang Feasible (LatestGKSK)

Energi panas bumi dapat dimanfaatkan dengan dua cara yaitu secara langsung dan tidak langsung. Pemanfaatan panas bumi secara langsung contohnya ialah pada pemandian air panas dan penghangatan ruangan. Sementara pemanfaatan secara tidak langsung terjadi pada PLTP yang bekerja dengan mengonversikan energi panas menjadi energi listrik. Pemfokusan pemanfaatan energi panas bumi memang terletak pada pemanfaatan secara tidak langsung karena energi listrik merupakan jenis energi high grade. Hal ini berbeda dengan energi panas yang merupakan jenis energi low grade (Mackay, 2008).

Indonesia memiliki $40 \%$ total potensi energi panas bumi di dunia (Setiawan, 2014). Besarnya potensi ini membuat pemerintah optimis akan pengembangan energi panas bumi di Indonesia. Berdasarkan Peraturan Presiden Nomor 22 Tahun 2017 tentang Rencana Umum Energi Nasional (RUEN), pemerintah Indonesia memproyeksikan target pengembangan energi panas bumi sebesar 7200 MW pada tahun 2025. Hal ini dilakukan sebagai salah satu upaya dalam mencapai target energi terbarukan 23\% pada tahun 2025. Karena hingga tahun 2020 total kapasitas PLTP di Indonesia baru mecapai sekitar 2100 MW, penambahan 5100 MW dalam 5 tahun kedepan tentu membutuhkan strategi dan dukungan pemerintah yang matang dan ambisius dalam mengatasi kendala terbesar pengembangan energi panas bumi di Indonesia. 


\section{PEMBAHASAN}

Beberapa keunggulan yang dimiliki energi panas bumi menjadikan jenis energi ini memiliki karakteristik spesial tersendiri dibandingkan jenis energi terbarukan lainnya. Hal ini dikarenakan karakteristik jenis energi terbarukan lainnya yang memiliki banyak tantangan sehingga membuatnya sulit untuk dijadikan sebagai penopang energi listrik nasional ditambah dengan besar permintaan listrik yang akan terus meningkat seiring bertambahnya populasi dan gaya hidup masyarakat di Indonesia.

Pengembangan energi panas bumi dengan langkah yang serius dan strategis akan dapat menjadikannya sebagai sumber pemasok energi listrik nasional yang dapat diandalkan. Energi panas bumi dengan nilai potensi yang besar ini tidak hanya diharapkan dapat membantu pemerintah Indonesia dalam melepas ketergantungan nasional akan bahan bakar fosil yang kotor dan diprediksi akan habis dalam waktu dekat, namun juga dapat membantu dalam menurunkan emisi GRK nasional demi keselamatan jutaan umat manusia akibat krisis iklim di seluruh dunia.

\section{A. Keunggulan Energi Panas Bumi}

\section{1) Rendah Emisi GRK}

Dalam proses pemanfataannya, energi panas bumi tidak serta merta tak menghasilkan GRK sama sekali. Hasil perhitungan jumlah emisi GRK yang dihasilkan pada PLTP memiliki nilai yang berbeda-beda. Hal ini dikarenakan faktor site-specific dan region-specific pada tiap PLTP yang berbeda (Report, 2011) ${ }^{1}$.

Namun, Interngovernmental Panel on Climate Change (IPCC) pada tahun 2014 mengeluarkan laporan mengenai hasil perhitungkan range emisi GRK pada jenis pembangkit listrik yang berbeda. Hasil laporan tersebut dituangkan dalam nilai minimum, median, dan maksimum. Perhitungan IPCC pada emisi GRK ini dijelaskan dalam satuan gram $\mathrm{CO}_{2}$-equivalent/kWh. Satuan $\mathrm{CO}_{2}$-equivalent ialah jenis GRK yang bermacam-macam, seperti metan dan nitrus oksida, dihitung ke dalam satuan jumlah $\mathrm{CO}_{2}$ yang mana nilainya disesuaikan dengan tingkat kemampuannya dalam memanaskan suhu bumi yang setara dengan tingkat $\mathrm{CO}_{2}$.

1 the world emits approximately 27 gigatonnes of $\mathrm{CO}_{2} \mathrm{e}$ from multiple sources, with electrical production emitting 10 gigatonnes, or approximately $37 \%$ of global emissions. In addition, electricity demand is expected to increase by $43 \%$ over the next 20 years. This substantial increase will require the construction of many new power generating facilities and offers the opportunity to construct these new facilities in a way to limit GHG emissions. There are many different electrical generation methods, each having advantages and disadvantages with respect to operational cost, environmental impact, and other factors. In relation to GHG emissions, each generation method produces GHGs in varying quantities through construction, operation (including fuel supply activities.

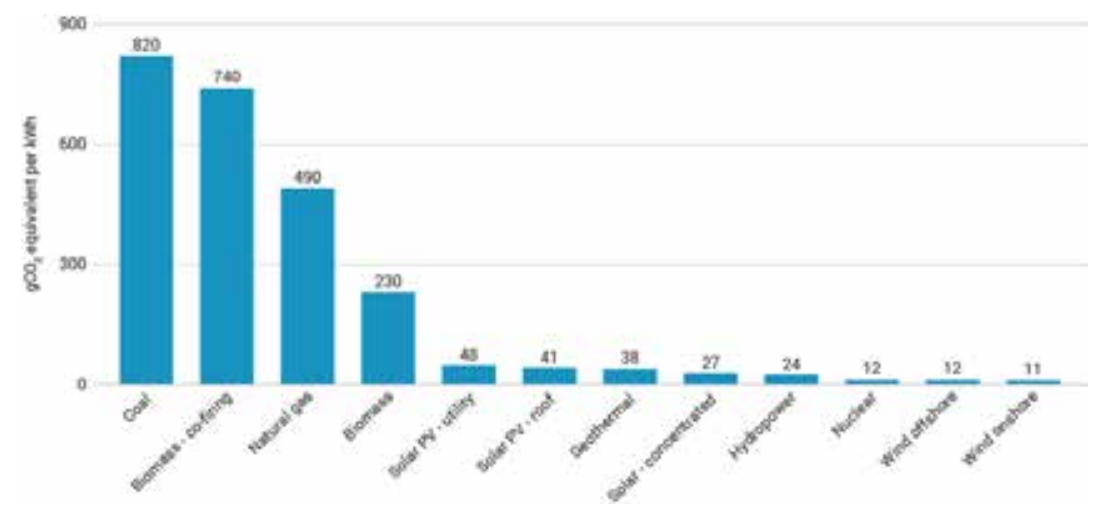

Gambar 2. Nilai Median Emisi pada tiap Jenis Pembangkit Listrik (Intergovernmental Panel on Climate Change and Intergovernmental Panel on Climate Change, 2015) 
Berdasarkan laporan IPCC tersebut, ditemukan bahwa emisi GRK yang dihasilkan PLTP ternyata lebih rendah dibandingkan dengan jenis energi terbarukan seperti biomassa dan solar PV dimana biomassa memiliki nilai median GRK sebesar $230 \mathrm{gCO}_{2}$-equivalent/kWh, solar PV utility sebesar $48 \mathrm{gCO}_{2}$-equivalent/ $\mathrm{kWh}$, dan PLTP sebesar $38 \mathrm{gCO}_{2}$-equivalent/ $\mathrm{kWh}$. Data ini menggambarkan keuntungan besar dalam memanfaatkan energi panas bumi sebagai langkah pemerintah Indonesia dalam menurunkan emisi GRK nasional yang mana targetnya tertera pada NDC yaitu sebesar 29\% dibawah skenario Business as Usual (BaU) pada tahun 2030.

\section{2) Tidak Bersifat Intermittent}

Energi panas bumi dapat dikategorikan sebagai energi terbarukan maupun tidak terbarukan tergantung pada bagaimana suatu proyek PLTP dikelola. Jika proyek PLTP mampu mengendalikan tekanan dan temperatur pada reservoir dengan baik dan berkelanjutan, sehingga panas dalam reservoir bisa terus digunakan, maka energi panas bumi dapat digolongkan ke dalam jenis energi terbarukan.

Karena pemegang kendali akan suplai sumber energi panas pada PLTP berada pada kendali manusia dalam mengolah temperatur reservoir maka energi panas bumi ini dapat menghasilkan besar daya energi listrik dalam nilai yang stabil karena tidak bergantung pada cuaca. Hal ini berbeda dengan Pembangkit Listrik Tenaga Surya (PLTS) dan Pembangkit Listrik Tenaga Bayu (PLTB) yang menghasilkan daya listrik yang bersifat intermittent karena ketergantungannya pada intensitas cahaya matahari dan kecepatan angin.

Kesulitan lainnya pun muncul dalam mengembangkan PLTS dan PLTB karena dibutuhkannya storage untuk menyimpan energi listrik agar dapat digunakan saat permintaan listrik sedang tinggi. Kesulitan dalam menyimpan energi listrik ini terjadi terutama pada pembangkit listrik dengan skala yang besar. Kemudahan energi panas bumi yang mampu menghasilkan daya listrik stabil membuatnya menjadi lebih feasible untuk diaplikasikan karena tidak membutuhkan banyak pertimbangan seperti jenis energi terbarukan angin dan sinar surya.

\section{3) Kemampuannya sebagai Base Load}

Dalam satu hari, jumlah permintaan listrik tidaklah selalu stabil. Setiap tempat memiliki curve permintaan listrik yang berbeda-beda tergantung pada kebutuhan masyarakat setempat. Dalam laporannya, Energy Sector Management Assistance Program (ESMAP) memberikan contoh keadaan permintaan listrik suatu tempat yang mana terdapat dua peak load kebutuhan listrik dalam satu hari (gambar 3).

Karakteristik energi panas bumi yang menghasilkan daya listrik stabil membuatnya memiliki kemampuan untuk menjadi base load dalam bauran energi listrik untuk memenuhi permintaan listrik minimum masyarakat setempat. Hal ini sangat memudahkan dalam menyusun sumber energi listrik suatu tempat dengan potensi panas bumi yang besar karena permintaan energi listrik minimumnya dapat dipenuhi dengan memanfaatkan potensi energi panas bumi yang ada di wilayah tersebut.

Bahkan, jika suatu proyek PLTP memiliki potensi panas bumi yang lebih besar, PLTP dapat dikembangkan lagi dan kelebihan energi listrik yang dihasilkan dapat dikirim ke wilayah lainnya melalui sistem transmisi guna memenuhi kebutuhan listrik minimum wilayah lain yang tidak memiliki sumber energi panas bumi. Keberadaan peak load kemudian dapat dipenuhi dengan memanfaatkan jenis energi terbarukan lainnya. 


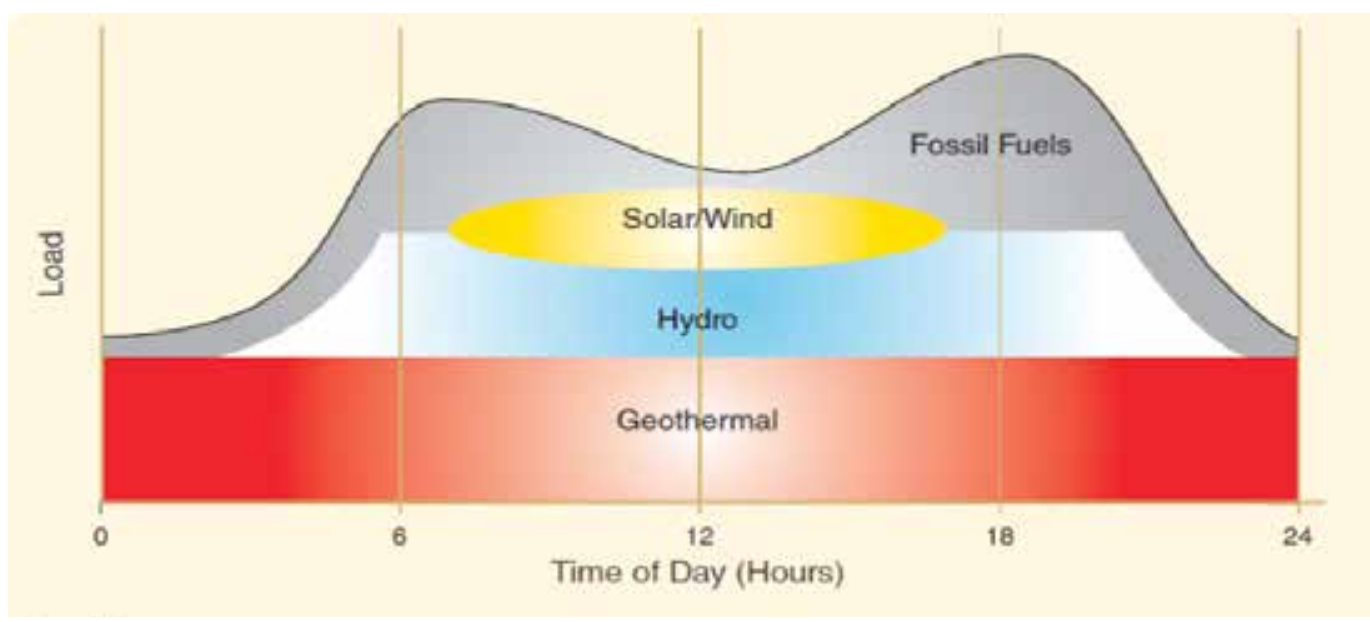

Gambar 3. Load Curve pada tiap Jenis Pembangkit Listrik (ESMAP, 2012)

Bahkan, jika suatu proyek PLTP memiliki potensi panas bumi yang lebih besar, PLTP dapat dikembangkan lagi dan kelebihan energi listrik yang dihasilkan dapat dikirim ke wilayah lainnya melalui sistem transmisi guna memenuhi kebutuhan listrik minimum wilayah lain yang tidak memiliki sumber energi panas bumi. Keberadaan peak load kemudian dapat dipenuhi dengan memanfaatkan jenis energi terbarukan lainnya.

\section{4) Kebutuhan Luas Area yang Kecil}

PLTP ternyata termasuk ke dalam jenis energi terbarukan yang paling kecil dalam kebutuhan luas area. Berdasarkan gambar 5, PLTP membutuhkan luas lahan paling kecil jika dibandingkan PLTB, PLTS, dan PLTH. Kebutuhkan luas area PLTP bahkan hampir 10 kali lebih kecil dibandingkan dengan PLTB.

Karakteristik energi terbarukan yang membutuhkan lahan yang luas ini membuatnya menjadi kurang feasible untuk diaplikasikan terutama dalam jangka waktu yang panjang. Hal ini dikarenakan pertumbuhan populasi manusia akan terus mengalami peningkatan setiap tahunnya. Kebutuhan akan area sebagai tempat tinggal masyarakat tentu juga akan terus meningkat seiring dengan bertambahnya jumlah penduduk yang ada.

Selain itu, kebutuhan akan pangan yang juga kian meningkat menyebabkan kebutuhan lahan untuk sektor agrikultur menjadi terus meningkat di masa depan. Jenis energi terbarukan dikhawatirkan akan bersaing dengan kebutuhan tempat tinggal serta sektor agrikultur. Di masa depan, pemanfaatan energi terbarukan lainnya dikhawatirkan akan memperparah konflik agraria di Indonesia. Pengaplikasian teknologi energi terbarukan seperti PLTS dan PLTB menjadi membutuhkan pertimbangan yang lebih rumit sehingga dibutuhkan perencanaan jangka panjang yang lebih matang.

Keunggulan-keunggulan yang dimiliki energi panas bumi dibandingkan jenis energi terbarukan lainnya menjadikannya cukup spesial sehingga mampu untuk dijadikan sumber pasokan energi listrik nasional yang bisa diandalkan. 


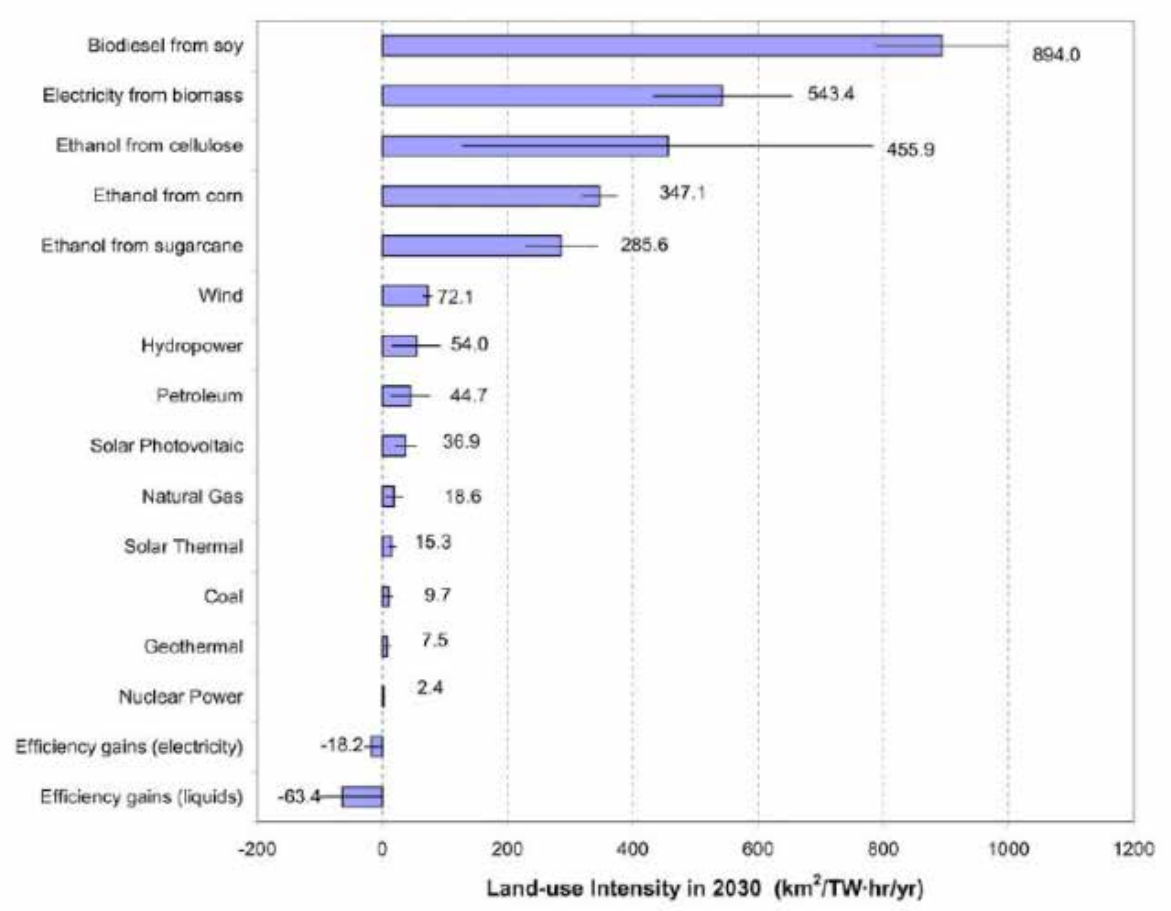

Gambar 5. Luas Area untuk Produksi Energi (McDonald et al., 2009)

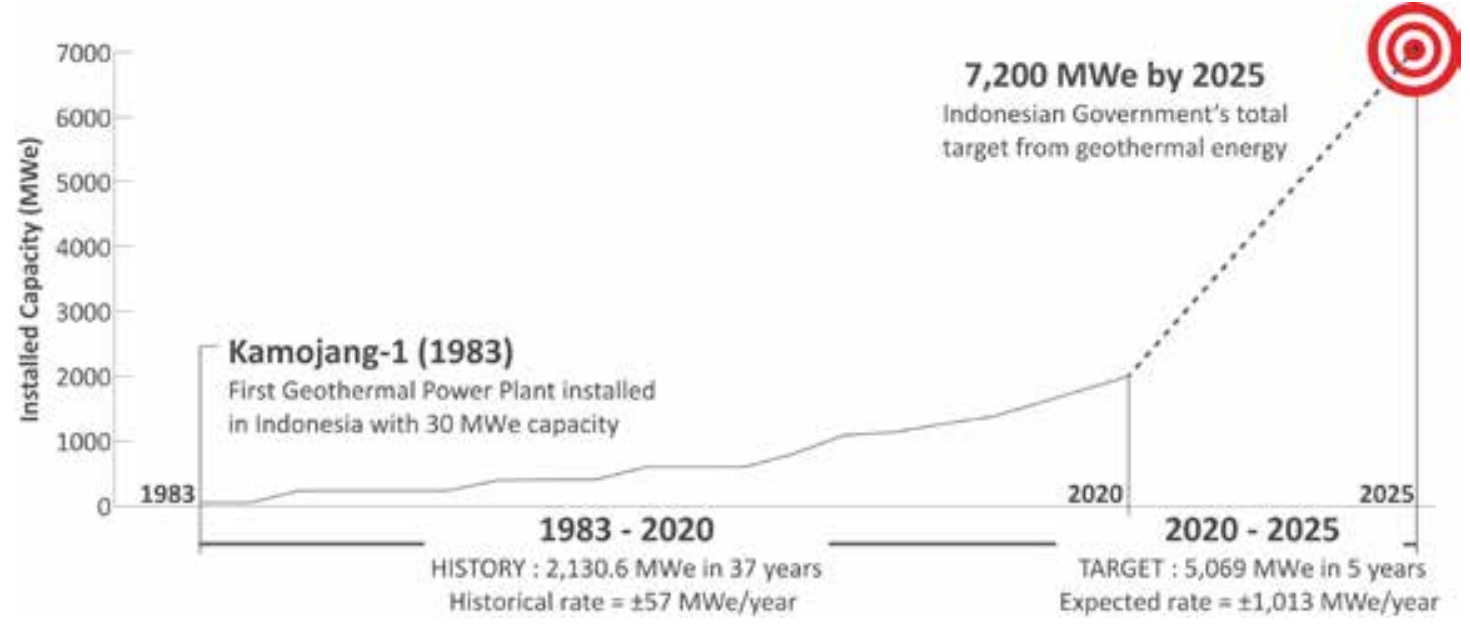

Gambar 6. Kapasitas PLTP Indonesia (modified from Purba, 2018 and EBTKE, 2020)

Potensinya yang begitu besar di Indonesia tentu menjadi peluang besar bagi pemerintah untuk mendongkrak jumlah energi terbarukan sesuai dengan target yang telah di tetapkan demi menurunkan ketergantungan energi fosil serta menurunkan emisi GRK nasional.

\section{B. Kendala Terbesar Pengembangan Panas Bumi}

PLTP Indonesia pertama kali dibangun pada tahun 1983 yang mana terletak di Kabupaten Bandung, Jawa Barat. Sejak PLTP Indonesia pertama kali dibangun hingga tahun 2020, terdapat sekitar 2100 MW kapasitas PLTP di 
Indonesia. Artinya ialah dalam kurun waktu 37 tahun, Indonesia baru bisa membangun PLTP dengan total kapasitas sebesar 2100 MW dari total besar potensinya yaitu sekitar 28000 MW.

Lambannya perkembangan energi panas bumi tidak hanya dialami Indonesia namun juga oleh negara-negara lainnya yang memiliki potensi energi panas bumi paling besar di dunia. Total kapasitas terpasang pada negaranegara terdepan dalam pengembangan panas bumi di dunia seperti Indonesia, Amerika, Filipina, dan Turki memang tidak terpaut jauh.
Artinya, kendala pengembangan panas bumi tidak serta merta hanya terletak pada regulasi kebijakan suatu negara namun juga terletak pada kendala teknis dalam proyek PLTP.

Berdasarkan laporan ESMAP, studi ini berargumen bahwa kendala terbesar dalam mengembangkan panas bumi ialah terletak pada tahap awal proyek yaitu pada tahap eksplorasi. Gambar 7 menggambarkan besarnya harga dan risiko yang ada pada setiap tahap proyek PLTP mulai dari tahap awal eksplorasi hingga tahap maintenance pembangkit.

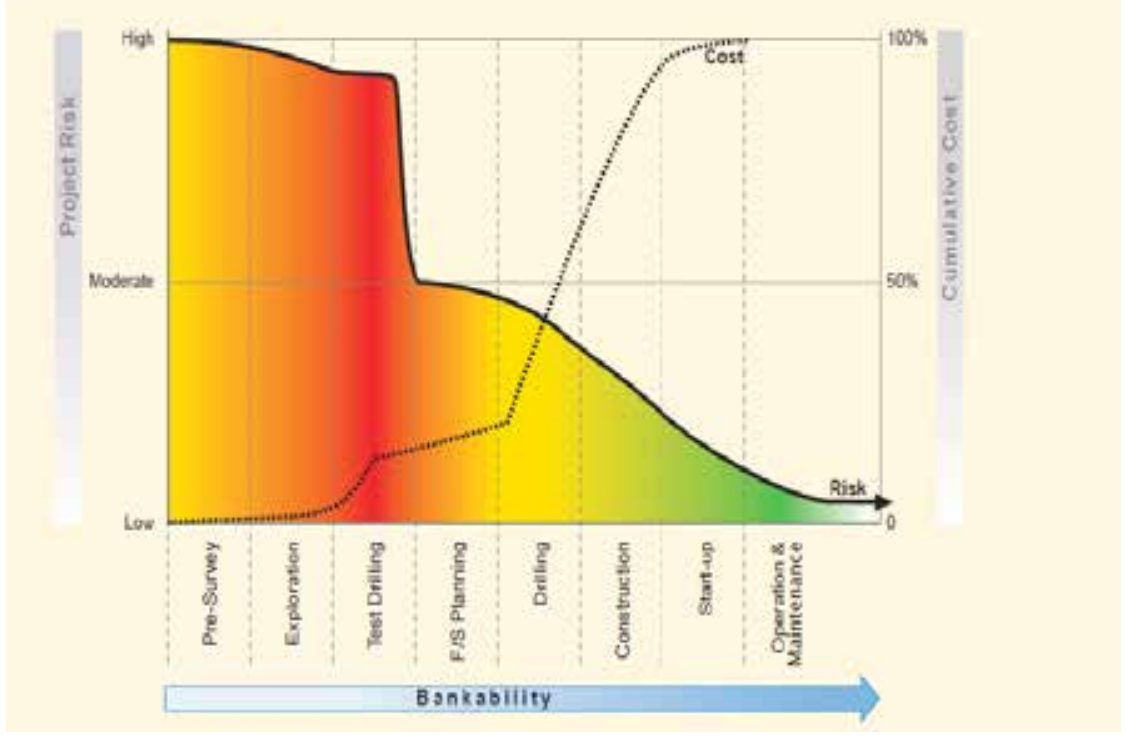

Gambar 7. Harga dan Risiko Proyek PLTP tiap Tahap (ESMAP, 2012)

Tahap awal eksplorasi ternyata memegang tingkat risiko tertinggi dalam proyek PLTP. Hal ini disebabkan karena hasil tahapan ini yang berasal dari interpretasi para ahli. Jika hasil survey Geofisika, Geokimia, dan Geologi (3G) menginterpretasi bahwa suatu tempat memiliki sebuah reservoir dengan nilai temperatur dan tekanan yang cukup baik untuk proyek PLTP.

Maka satu-satunya cara untuk membuktikan kebenaran interpretasi tersebut ialah dengan melakukan pengeboran (test drilling).
Sementara itu, total biaya yang harus dikeluarkan untuk melakukan keseluruhan tahap eksplorasi termasuk drilling dengan total 3 sumur ialah sebesar USD 34,1 juta (PT Pertamina Geothermal Energy, 2013). Besarnya dana yang dikeluarkan ini belum tentu akan berbuah manis karena jika ternyata setelah dilakukan drilling tidak terdapat reservoir sesuai dengan yang telah diinterpretasikan pada survey awal 3G maka biaya besar tersebut harus ditanggung pengembang panas bumi yang mana tentu sangat merugikan perusahaan. 
Bahkan jika ingin kembali melakukan drilling di tempat sekitaran sumur yang telah dibor diperlukan tidak hanya biaya drilling namun juga biaya pembebasan lahan, well pad, dan jalan masuk. Jika ternyata tahap drilling sukses maka dimulailah tahapan konstruksi PLTP dengan biaya yang lebih tinggi lagi namun dengan tingkat risiko yang jauh lebih kecil. Hal ini dikarenakan tingkat ketidakpastian yang sudah jauh lebih rendah karena sumber panas bumi yang baik telah terverifikasi keberadaannya.

\begin{tabular}{|c|l|c|}
\hline NO & \multicolumn{1}{|c|}{ JENIS KEGIATAN } & $\begin{array}{c}\text { ESTIMASI BIAYA } \\
\text { (US\$) juta }\end{array}$ \\
\hline 1. & $\begin{array}{l}\text { Survey Geologi, Geofisika, Geokimia } \\
\text { (meneNtukan tapak bor) }\end{array}$ & 7 \\
\hline 2. & AMDAL, SIPPA, IPPKH & 0,1 \\
\hline 3. & Pembebasan lahan & 1 \\
\hline 4. & $\begin{array}{l}\text { Well Pad + Jalan Masuk } \\
\text { (Asumsi 6 km) }\end{array}$ & 5 \\
\hline 5. & Sumur & 21 \\
\hline & TOTAL & 34,1 \\
\hline
\end{tabular}

Gambar 8. Total Biaya Eksplorasi (PT Pertamina Geothermal Energy 2013)

Studi ini berpendapat bahwa besarnya risiko serta biaya awal yang harus dihadapi pengembang panas bumi untuk melaksanakan tahap eksplorasi telah membuat pengembangan energi panas bumi menjadi lamban selama 37 tahun kebelakang. Pengembangan panas bumi tidak hanya membutuhkan bantuan technical assistance namun juga dibutuhkan bantuan dana yang sangat besar demi memikat investor pada sektor panas bumi.

Bantuan dana serta technical assistance ini sangat dibutuhkan untuk mempercepat pelaksanaan eksplorasi panas bumi di Indonesia agar target kapasitas PLTP di Indonesia bisa mencapai target 7200 MW pada tahun 2025 .

\section{Upaya Pemerintah dalam Mendukung Eksplorasi Panas Bumi \\ 1) Pembiayaan Infrastruktur Panas Bumi (PSIP)}

Peraturan Menteri Keuangan (PMK) Nomor 62/PMK.08/2017 telah resmi ditandatangani pada tanggal 12 Mei 2017. PMK tersebut berisikan hal-hal mengenai Pengelolaan Dana Pembiayaan Infrastruktur Sektor Panas Bumi pada Perusahaan Perseroan (Persero) PT Sarana Multi Infrastruktur (PT SMI). PKM tersebut diterbitkan dalam rangka mengatur pengeloaan dana PSIP yang akan dikelolah oleh PT SMI. Pembiayaan PSIP, atau Geothermal Fund, merupakan upaya pemerintah dalam meningkatkan pengembangan panas bumi di Indonesia melalui bentuan finansial.

Berdasarkan data pada artikel website Kementerian Energi dan Sumber Daya Mineral (ESDM) bagian Direktorat Jenderal Energi Baru Terbarukan dan Konservasi Energi (EB- 
TKE), pendanaan PSIP tersebut nilainya sebesar 3,7 triliun rupiah dimana 3 triliun rupiah berasal dari APBN 2017 sementara sisahnya sebesar 7 miliar rupiah berasal dari dana hibah the World bank yang pengelolaannya akan ditangani oleh PT SMI.

Tujuan pendanaan tersebut ialah untuk mendukung kegiatan-kegiatan panas bumi salah satunya ialah kegiatan eksplorasi. Bantuan yang dilaksanakan oleh PT SMI ini ialah pinjaman dana, penyertaan modal, serta penyediaan data dan informasi panas bumi dimana untuk penyediaan data dan informasi panas bumi, PT SMI dapat bekerja sama dengan lembaga internasional.

\section{2) Bantuan Hibah Internasional}

Kementerian Energi dan Sumber Daya Mineral (ESDM) bersama Kementerian Keuangan menginisiasi program Government Drilling dengan tujuan untuk mengurangi risiko hulu pengeboran pada kegiatan eksplorasi panas bumi di Indonesia. Kegiatan ini diharapkan dapat memikat lebih banyak investor dalam mengembangkan panas bumi di Indonesia.

Pendanaan program Government Drilling berasal dari Geothermal Energy Upstream Development Project (GEUDP). Sumber dana GEUDP ialah sebesar USD 49 juta yang berasal dari Clean Technology Fund (CTF) untuk biaya pengeboran. Selain itu, ada dana lain sebesar USD 6.25 juta sebagai biaya technical assistance yang berasal dari Global Environment Facility (GEF) (Dirjen EBTKE, 2018).

Pendanaan GEUDP ini juga dilengkapi dengan dana pendampingan pemerintah yang berasal dari PISP. Cangkupan program Government Drilling ini mulai dari pengusulan lokasi sampai pemberian Izin Panas Bumi (IPB) oleh menteri ESDM.

Selain itu, pada tahun 2020, pemerintah Indonesia juga telah berhasil bekerja sama ber- sama institusi-institusi internasional lainnya dalam sebuah program bernama Geothermal Resource Risk Mitigation (GREM). Program GREM merupakan bantuan dana yang berasal dari the World Bank, Green Climate Fund (GCF), Clean Technology Fund (CTF), Energy Sector Management Assistance Program (ESMAP), Global Infrasctructure Facility (GIF), serta dana PISP (PT SMI, 2020).

Program GREM bertujuan untuk meningkatkan investasi pengembangan panas bumi di Indonesia dan mendukung debitur (pengembang panas bumi), baik sektor publik maupun swasta, dalam menurunkan emisi GRK nasional. Fitur utama GREM ialah bantuan alokasi risiko sumber daya dalam pelaksanaan eksplorasi panas bumi dimana debitur dimungkinkan mendapatkan penurunan pengembalian kewajiban.

Total bantuan pendanaan dalam program ini ialah sebesar USD 465 juta yang mana terdiri dalam dua komponen. Komponen pertama merupakan fasilitas bantuan dana sebesar USD 455 juta yang bertujuan untuk memitigasi risiko dalam pelaksanaan eksplorasi panas bumi di Indonesia. Sementara untuk komponen kedua, fasilitas bantuan dana bertujuan untuk mendukung pelaksanaan eksplorasi panas bumi berupa dukungan technical assistance dengan nilai dana sebesar USD 10 juta.

Gambar 9 menjelaskan cangkupan pembiayaan GREM pada pelaksanaan eksplorasi panas bumi untuk pengembang sektor publik dan swasta. Tenor peminjaman pada program GREM ini berkisar 4-6 tahun. 


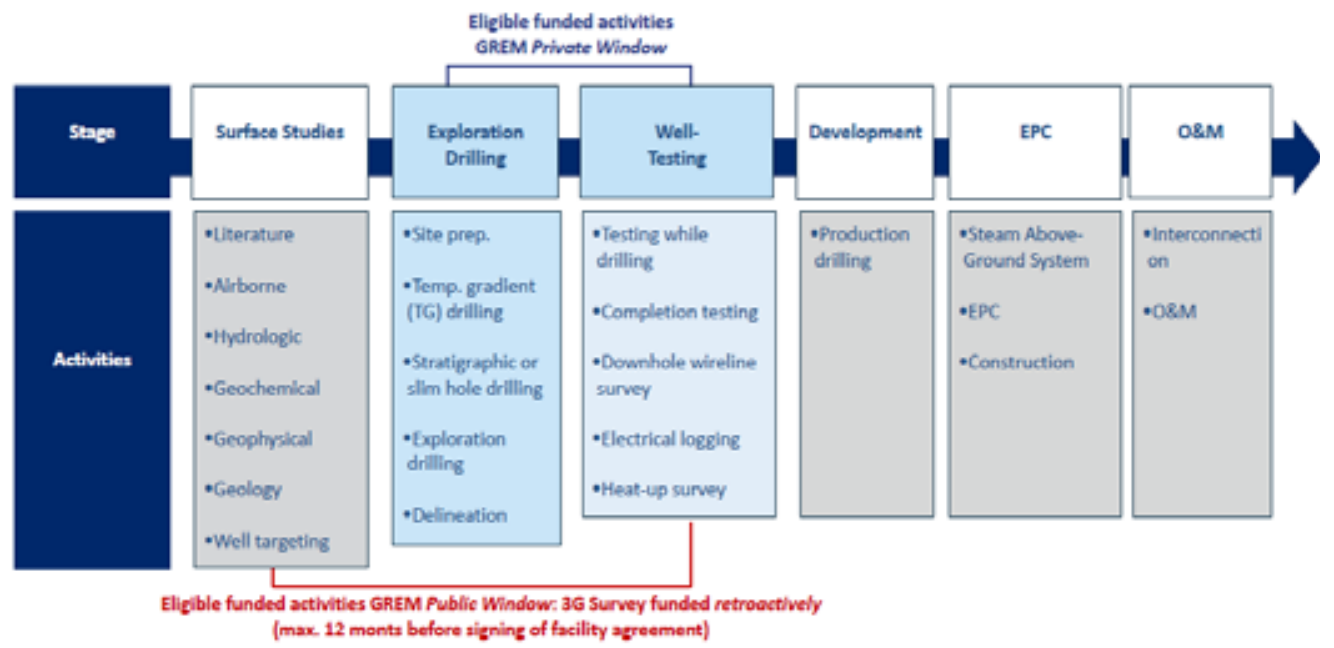

Gambar 9. Cangkupan Pembiayaan GREM (PT SMI, 2020)

\section{3) Penugasan Survey Pendahuluan (PSP) dan Penugasan Survey Pendahuluan dan Eksplorasi (PSPE)}

Pemerintah Indonesia juga terus mempercepat perkembangan panas bumi di Indonesia melalui Penugasan Survey Pendahuluan (PSP) dan Penugasan Survey Pendahuluan dan Eksplorasi (PSPE) sesuai pada Peraturan Menteri ESDM Nomor 36 Tahun 2017. Langkah ini diambil oleh pemerintah agar pengembang panas bumi yang telah memenuhi kriteria dapat langsung melakukan kegiatan eksplorasi yang telah disetujui oleh pemerintah.

PSP akan diberikan pemerintah kepada perguruan tinggi dan lembaga penelitian yang meliputi survey $3 G$ dan survey terpadu. Sementara PSPE akan diberikan kepada Badan Usaha yang meliputi kegiatan PSP ditambah dengan pengeboran dan perhitungan cadangan panas bumi. Biaya untuk melaksanakan kegiatan ini akan ditanggung oleh pihak-pihak yang bersangkutan.

\section{Rekomendasi Langkah Pemerintah dalam Mendukung Eksplorasi Panas Bumi}

Tingginya risiko dan biaya yang harus dihadapi pengembang panas bumi dalam kegiatan eksplorasi telah menjadi kendala yang cukup besar dalam mengembangkan kapasitas PLTP di Indonesia. Tingginya risiko akan tahap ekplorasi panas bumi menggambarkan pentingnya terobosan langkah pemerintah dalam mendukung kegiatan eksplorasi panas bumi demi mempercepat pengembangan kapasitas PLTP di Indonesia. Studi ini mengajukan beberapa rekomendasi langkah yang dapat diambil oleh pemerintah dalam mendukung kegiatan eksplorasi panas bumi di Indonesia.

\section{1) Pendirian Badan Eksplorasi Panas Bumi}

Demi mempercepat kegiatan eksplorasi panas bumi serta mendorong partisipasi pengembang panas bumi, dibutuhkan pendirian badan eksplorasi yang dapat dikontrol oleh pemerintah dimana memiliki tugas untuk mengelola kegiatan eksplorasi panas bumi di Indonesia. Badan eksplorasi ini juga diharapkan 
mampu melakukan pemeriksaan kualitas suatu data yang diperoleh dari hasil eksplorasi di Indonesia.

Pentingnya keberadaan badan ini terletak pada pada ketiadaan database nasional akan arsip data dan informasi panas bumi. Selain itu, badan eksplorasi ini juga akan memiliki banyak ahli yang terampil secara teknikal sehingga dapat mengelola kegiatan eksplorasi panas bumi menjadi lebih efisien karena tidak hanya dapat memberikan jasa ahli pada pengembang panas bumi namun juga dapat membantu apabila proyek PLTP kehilangan ahli karena suatu hal. Pendirian badan ini diharapkan mampu memberikan sinyal keseriusan pemerintah dalam mendukung kegiatan eksplorasi panas bumi di Indonesia kepada para investor.

Pengadaan badan eksplorasi ini bisa dilakukan dengan pendirian badan baru atau dapat juga dilakukan dengan penunjukkan badan yang telah ada oleh pemerintah seperti GeoDipa. Namun bagaimanapun konsep pendirian badan eksplorasi ini, badan ini harus memilki suvervisi ahli serta bersifat terampil secara teknis. Pendanaan dalam badan ini dapat berasal dari dana PSIP.

\section{2) Pembiayaan Kegiatan Eksplorasi}

Studi ini berargumen bahwa untuk mencapai target kapasitas PLTP Indonesia yang ambisius dibutuhkan langkah pemerintah yang tidak kalah ambisius seperti pembiayaan kegiatan eksplorasi panas bumi. Tingginya biaya eksplorasi panas bumi telah membuat banyak investor memiliki banyak pertimbangan akan keikutsertaannya dalam mengembangkan panas bumi di Indonesia. Terdapat beberapa cara dalam mendapatkan sumber dana untuk membiayai kegiatan eksplorasi panas bumi di Indonesia yaitu seperti penerapan kebijakan depletion premium serta reformasi subsidi ba- han bakar fosil menuju subsidi energi terbarukan.

Depletion premium atau pungutan premi energi fosil merupakan biaya atas pengambilan bahan bakar fosil yang telah menguras ketersediaan energi fosil nasional. Pungutan ini dapat diimplementasikan dengan memasukkan pungutan ke dalam setiap liter BBM yang dijual ke masyarakat. Dana hasil penerapan depletion premium ini selanjutnya dapat dimasukan ke dalam dana PSIP.

Dana PSIP yang jumlahnya menjadi lebih besar ini selanjutnya tidak hanya digunakan untuk memberikan pinjaman biaya eksplorasi namun digunakan untuk langkah yang lebih ambisius lagi yaitu pembiayai kegiatan eksplorasi panas bumi di Indonesia. Dukungan finansial ini dianggap dapat menarik lebih banyak investor panas bumi di Indonesia yang selama ini masih khawatir akan kegagalan dalam tahap eksplorasi yang sangat merugikan perusahaan.

Selain itu, sumber dana untuk kegiatan eksplorasi ini juga dapat berasal dari pengalihan subsidi energi fosil menuju energi terbarukan khususnya energi panas bumi. Reformasi subsidi energi fosil menuju energi bersih terbarukan sangatlah penting karena pemberian subsidi bahan bakar fosil yang selama ini dilakukan pemerintah dipandang telah mendorong pemborosan dalam konsumsi bahan bakar fosil serta menghambat investasi-investasi pengembangan energi terbarukan yang jauh lebih bersih dan berkelanjutan demi menjaga bumi dari bahaya krisis iklim.

Walaupun subsidi akan bahan bakar fosil seperti Bahan Bakar Minyak (BBM) dan Liquefied Petroleum Gas (LPG) telah mengalami penurunan, namun nilainya tetap cukup besar. Hal ini berbeda jauh dengan energi terbarukan yang masih belum mendapatkan dukungan finansial berupa subsidi dari pemerintah. Dana subsidi bahan bakar fosil ini dapat dia- 
lihkan untuk membiayai kegiatan eksplorasi panas bumi di Indonesia.

Selama bahan bakar fosil terus diberikan subsidi, maka kesetaraan bisnis (playing field) tidak dapat diraih oleh energi terbarukan. Penghapusan subsidi akan bahan bakar fosil memang cukup sensitif dan sulit secara politik. Namun ada banyak kasus international yang dapat dijadikan sebagai pembelajaran (Overland, Suryadi and Win, 2018).

PT PLN sangat berharap pemerintah Indonesia secara konsisten mengembangkan panas bumi. Dalam hal ini, dukungan pemerintah dibutuhkan untuk membiayai eksplorasi sehingga penawaran investasi kepada investor menjadi lebih baik dan jelas, sebab tanpa dukungan konkrit pemerintah, sulit bagi investor memulai pembangunan PLTP di Indonesia. (Mary et al., 2017).

Studi ini berargumen bahwa untuk mengembangkan kapasitas PLTP dengan cepat di Indonesia penting untuk memberikan perhatian lebih akan solusi dalam menghadapi kendala terbesar yang telah membuat perkembangan panas bumi di Indonesia begitu lamban selama 37 tahun kebelakang yaitu kendala tahap eksplorasi. Oleh karena itu, studi ini beranggapan bahwa kunci game changer dalam mengembangkan panas bumi terletak pada besarnya dukungan finansial yang diberikan pemerintah kepada pihak pengembang panas bumi di Indonesia untuk melakukan kegiatan eksplorasi.

Kendala akan pengembangan energi panas bumi telah terlihat dan diketahui. Hal yang masih belum terlihat ialah political will dan economic might yang kuat akan pengembangannya di Indonesia. Studi ini berpendapat bahwa penerapan kebijakan yang direkomendasikan pada studi ini akan memperlihatkan besarnya political will dan economic might pemerintah Indonesia terhadap pengembangan kapasitas PLTP di Indonesia.
Penambahan kapasitas PLTP sebesar 5100 MW dalam 5 tahun kedepan memang merupakan target yang sangat ambisius. Oleh karena itu, dibutuhkan langkah-langkah pemerintah Indonesia yang tidak kalah serius demi masa depan generasi selanjutnya yang aman akan pasokan listrik dan bahaya akan krisis iklim.

\section{KESIMPULAN}

Energi panas bumi di Indonesia merupakan salah satu jenis energi terbarukan dengan nilai potensinya kedua terbesar di dunia. Jika dibandingkan dengan jenis energi terbarukan lainnya, energi panas bumi memiliki beberapa keunggulan yang dapat menjadikannya sebagai sumber pasokan energi listrik nasional yang lebih feasible dan dapat diandalkan.

Secara keseluruhan, tahap eksplorasi memegang risiko tertinggi dalam sebuah proyek PLTP. Tingginya biaya awal dan ketidakpastian yang harus dihadapi pengembang panas bumi dianggap menjadi kendala terbesar dalam pengembangan panas bumi di Indonesia. Beberapa langkah telah dilakukan pemerintah untuk mendukung tahap eksplorasi seperti dana PSIP, bantuan hibah dari institusi internasional, serta kegiatan PSP dan PSPE. Namun studi ini menganggap bahwa masih diperlukannya langkah-langkah yang lebih serius dalam mendukung kegiatan eksplorasi panas bumi di Indonesia.

Studi ini mengajukan beberapa rekomendasi yang dapat diambil oleh pemerintah sebagai bentuk dukungan atas kegiatan eksplorasi panas bumi di Indonesia yaitu pendirian badan eksplorasi panas bumi serta pembiayaan kegiatan eksplorasi yang mana sumber dananya dapat berasal dari penerapan kebijakan depletion premium dan pengalihan subsidi bahan bakar fosil.

Besarnya keuntungan dalam memanfaatkan energi panas bumi namun masih rendahnya 
peranan panas bumi dalam bauran energi nasional menggambarkan pentingnya pemerintah dalam mengambil langkah ambisius demi mencapai target kapasitas PLTP sebesar 7200 MW pada tahun 2025. Bahaya akan krisis iklim dan bahan bakar fosil yang kian menipis sudah berada di depan mata. Sudah saatnya pemerintah mengubah sistem energi nasional menuju energi bersih terbarukan demi kehidupan yang layak untuk masa depan generasi selanjutnya.

\section{DAFTAR PUSTAKA}

Dirjen EBTKE (2017) Potensi Panas Bumi Indonesia Jilid 2, Kementerian Energi dan Sumber Daya Mineral.

Dirjen EBTKE (2018) Doing Business in Geothermal. http://igis.esdm.go.id/igis/img/Proses_ Bisnis.pdf

Dirjen EBTKE (2020) Pengembangan Panas Bumi, Presentation, Kementrian Energi dan Sumber Daya Mineral.

ESMAP (2012) 'Geothermal Handbook : Planning and Financing Power Generation', World Bank Technical Report.

Fridleifsson, I. B., Bertani, R. and Huenges, E. (2008) 'The possible role and contribution of geothermal energy to the mitigation of climate change', IPCC Scoping Meeting on Renewable Energy Sources.

Intergovernmental Panel on Climate Change and Intergovernmental Panel on Climate Change (2015) 'Technology-specific Cost and Performance Parameters', in Climate Change 2014 Mitigation of Climate Change. doi: 10.1017/cbo9781107415416.025.

Judge, W. D., Xiao, Z. W. and Kipouros, G. J. (2017) 'Application of rare earths for higher efficiencies in energy conversion', in Minerals, Metals and Materials Series. doi: 10.1007/978-3319-51085-9_4.

LatestGKGS (2020) Geography: Earth layer, earth composition, temperature, pressure. https:// www.latestgkgs.com/geography-5298-a

Li, Y. et al. (2009) 'Climate change and drought: a risk assessment of crop-yield impacts', Climate Research.doi: $10.3354 /$ cr00797.

Mackay, J. C. D. (2008) 'Sustainable Energy — without the hot air Synopsis', Energy.

Mary, R. T. et al. (2017) 'Panas Bumi Sebagai Harta Karun Untuk Menuju Ketahanan Energi', Ketahanan Nasional.

Masum, M. and Ali Akbar, M. (2019) 'The Pacific Ring of Fire is Working as a Home Country of Geothermal Resources in the World', in IOP Conference Series: Earth and Environmental Science. doi: 10.1088/1755-1315/249/1/012020.

McDonald, R. I. et al. (2009) 'Energy sprawl or energy efficiency: Climate policy impacts on natural habitat for the United States of America', PLOS ONE. doi: 10.1371/journal. pone.0006802.

Olivier, J. G. J. and Peters, J. A. H. W. (2020) 'Trends in Global CO2 and Total Greenhouse Gas 
Emissions: Report 2019', PBL Netherlands Environmental Assessment Agency.

Overland, I., Suryadi, B. and Win, U. T. (2018) 'Energy Subsidy Reform: An International Comparative Perspective on Myanmar', SSRN Electronic Journal. doi: 10.2139/ ssrn.3023148.

PT Pertamina Geothermal Energy (2020).

PT SMI. (2020). 'Geothermal Resource Risk Mitigation'. https://ptsmi.co.id/wp-content/ uploads/2020/09/Geothermal-Resource-Risk-Mitigation-GREM-PT-SMI.pd

Purba, D. P. (2020) 'Investigation on Geothermal Resource Assessment Methods in Reducing Exploration Risk in Indonesia Geothermal System', Master of Energy Research Project Report in University of Auckland (unpublished).

Report, W. N. A. (2011) 'Comparison of Lifecycle Greenhouse Gas Emissions of Various Electricity GenerationSources', World Nuclear Association.

Setiawan, H. (2014) 'Geothermal Energy Development in Indonesia: Progress, Challenges and Prospect', International Journal on Advanced Science, Engineering and Information Technology. doi: 10.18517/ijaseit.4.4.405.

Yang, L. et al. (2014) 'Progress in the studies on the greenhouse gas emissions from reservoirs', Acta Ecologica Sinica. doi: 10.1016/j.chnaes.2013.05.011. 